\title{
Making timber plantations an attractive business for smallholders
}

\author{
Dede Rohadi, Tuti Herawati, Christine Padoch and Digby Race
}

\section{Key points}

- The businesses of most smallholder timber growers are not strictly market-oriented. Consequently, opportunities to make better income from timber selling are often lost.

- Timber plantations generate important additional income for farmers. In Gunungkidul district, Indonesia, where smallholder teak plantations are grown, timber selling contributes about 15\% of farmers' total income.

- There is a wide range in timber prices at village and district levels but the farm-gate price generally lies at the lower end of the range. This is because of: (i) poor quality of logs produced by farmers; (ii) low bargaining power of farmers when selling their timber; and (iii) high transaction costs due to timber market regulations.

- Government agencies responsible for extension programs need to encourage farmers to improve their business skills in managing timber plantations. Priority efforts need to address farmers':

- $\quad$ knowledge about timber markets and prices, market access and quality standards;

- silvicultural skills, in particular thinning and pruning of their timber plantations;

- collective timber marketing and developing linkages with timber industries.

- In order to reduce transaction costs in timber marketing, both central and regional governments need to simplify the regulations for smallholders to trade timber. Timber certification for smallholders, such as the TLAS (Timber Legality Assurance System) should provide a clear incentive to smallholders and should replace their obligation to provide a timber certificate of origin or SKAU (Surat Keterangan Asal Usu).

\section{Introduction}

Smallholder timber plantations exist in various forms in Indonesia. Farmers may plant trees for timber on their private lands which is known as hutan rakyat, or on state forest lands under various schemes, such as hutan kemasyarakatan $(\mathrm{HKm})$, hutan tanaman rakyat (HTR) or hutan desa. Despite different schemes and rules, farmers are the main actors in smallholder timber plantation businesses. Farmers' decisions on investing resources and managing their timber plantations are important in determining the benefits they realize.

Smallholder timber plantations play important roles in forestry development in Indonesia. Various initiatives are being promoted by the government through a number of social forestry programs. Their main objective is to reduce poverty, in particular in rural areas, increase forest cover and increase wood supply to support industries (Ministry of Forestry Regulation No. P.01/2004').

1 Ministry of Forestry Regulation No. P.01/2004 on local community empowerment within and around forest areas in Social Forestry, Article 1, and Paragraph (5) stated "Social Forestry is a system of management of forest resources in state and or private forests that provides opportunities to the local community as principal or partner in forest management to improve livelihood and promote sustainable forest."
Despite efforts to increase the extent of smallholder timber plantations across the country, the expansion of the total plantation area so far has been slow. The current total area of smallholder timber plantations is about 2.8 million ha (Forest Industries Roadmap 20132), with most in the form of hutan rakyat. The total area of smallholder plantations in state forests is only $8000 \mathrm{ha}^{3}$. This indicates that smallholders do not view timber plantations as an attractive business opportunity.

Recent research has identified the following as challenges that currently prevent smallholders from maximizing the benefits from their timber plantation businesses:

- Farmer tree growers tend to be price takers in their timber plantation businesses due to lack of market access, limited business expertise and lack of capacity in applying good silvicultural practices. These factors weaken their bargaining position.

- Farmer tree growers are constrained by timber trade regulations that result in high transaction costs.

\footnotetext{
2 Presented by the Director General of Forestry Enterprise Development (Bina Usaha Kehutanan) on Panel Discussion "Menjawab Tantangan Indonesia Raja Kayu Dunia", Jakarta, 22 May 2014.

3 Based on Directorate General of Forestry Enterprise Development, the current planted HTR area is only 7986 ha, representing 4\% of total granted permits, or $1 \%$ of the currently allocated area for HTR development.
} 


\section{Timber plantations in farmers' livelihood portfolios}

Government and development agencies need to understand the role that timber plantation activities play in farmers' livelihood portfolios. A previous study (Rohadi et al. 2012) concluded that timber is not the main source of income for farmer households, although it is an important contributor to their incomes. Timber sales contribute about 15\% of total household income (Figure 1). In some areas, especially in Java, farmers see timber plantations as an important element of their farming systems. In Gunungkidul district (Java) in spite of limited land ownership, farmers allocate more than 10\% of their land to planting teak (Tectona grandis) for timber.

A recent study of community-based commercial forestry (CBCF) conducted a social dimension analysis and forestry livelihood framework assessment in five districts in Indonesia (Gunungkidul, Pati, Sumbawa, Bulukumba and Konawe Selatan). The study reported that the contribution from timber sales tends to be higher among middle income and wealthy farmers (Van de Fliert, 2013; Oktalina et al. 2014). This indicates that timber plantation businesses may increase in importance as farmers improve their incomes.

Planting timber by farmers has also become a tradition in some communities, with experience inherited from older generations. Timber plantations are seen by farmers as an important activity to improve the local environment and increase social status. Farmers have also been encouraged to plant timber by outsiders through both government and corporate investment programs.

\section{Challenges of smallholder timber plantation practices}

Research findings show that farmers manage their timber crops in traditional ways, especially when viewed from a business perspective. Due to limited access to loans, most farmers harvest timber only when they have an urgent need for cash, and their focus is on the amount of cash needed rather than on the existing timber market price. Such urgent needs for cash also often force farmers to harvest their timber before it reaches the optimum size for sale (Rohadi et al. 2012; Stewart et al. 2014a).

Farmers sell timber in the form of trees instead of logs. They generally do not have the skills and capital to harvest and sell timber directly to timber depots or sawmills. In addition, smallholder timber tends to be low quality, small in diameter, with knots and other defects and not straight. This is partly because most farmers do not use appropriate silvicultural practices, particularly thinning and pruning (Rohadi et al. 2012; Stewart et al. 2014a).

Men are more often involved in timber management practices than women, while women play a greater role in non-timber forest product (NTFP) harvesting and the financial aspects of timber production. When farmers work as individuals in the timber business they may weaken their bargaining

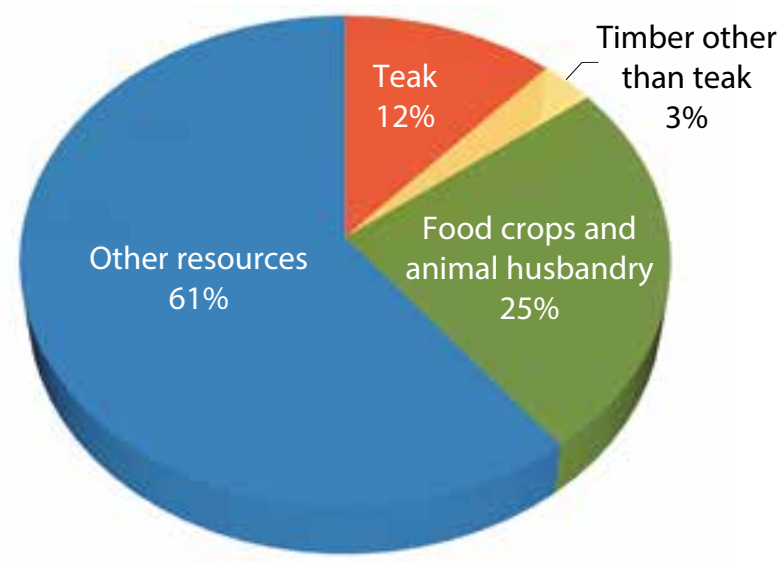

Figure 1. Average income share of teak plantation in household portfolios (from interviews with 31 household respondents in Gunungkidul district, Yogyakarta; Rohadi et al. 2012).

power in selling timber. Effective timber cooperatives are rare in Indonesia due to an apparent lack of appropriate organizational capacity, lack of extension services and lack of trust among group members (Van de Fliert et al. 2013).

\section{Smallholder timber marketing}

The CBCF research effort included value chain analyses of smallholder timber. Findings revealed that for a given timber species, market prices for smallholder timber varied significantly with wood quality. The price of teak logs in the five districts varied from IDR 500,000 to IDR 5 million per $\mathrm{m}^{3}$. The price of sengon (Paraserianthes falcataria (L.) Nielsen) logs varied from IDR 395,000 to IDR 1.15 million per $\mathrm{m}^{3}$. As shown in Table 1, diameter size and log form (free from defects) are the most important factors in determining timber grades (Stewart et al. 2014 a).

Research has found that smallholder timber market structures such as numbers and diversity of market actors (middlemen, processors and traders) varied significantly with location. In Java, the market is relatively developed and is moving toward perfect market competition. The number of middlemen in Java (Gunungkidul and Pati) was higher than in areas outside Java (Sumbawa, Bulukumba and Konawe Selatan). Figure 2 compares the marketing chains of smallholder timber in Gunungkidul, Yogyakarta (in Java) and Sumbawa, West Nusa Tenggara (outside Java).

Middlemen play an important role in smallholder timber marketing. The profit share of middlemen was not always greater than those of timber growers but they may still achieve significant profits in a much shorter time than growers (Stewart et al. 2014a).

Current regulations surrounding harvesting permits and timber transport documents tend to create marketing barriers and high transaction costs in timber marketing. In Sumbawa, 
Table 1. Price variation for smallholder timber at village and district levels in Gunungkidul (teak) and Pati (sengon) districts.

\begin{tabular}{|c|c|c|c|c|}
\hline No. & $\begin{array}{l}\text { Timber } \\
\text { species }\end{array}$ & Grade & $\begin{array}{l}\text { Diameter } \\
(\mathrm{cm})\end{array}$ & $\begin{array}{l}\text { Price } \\
(\text { IDR } \\
\left.1000 / \mathrm{m}^{3}\right)\end{array}$ \\
\hline \multirow[t]{6}{*}{1} & \multirow{6}{*}{$\begin{array}{l}\text { Teak (Tectona } \\
\text { grandis) - slow } \\
\text { growth }\end{array}$} & $\mathrm{A} 1$ (DL) & $<13$ & $500-700$ \\
\hline & & A1 (UP) & $16-19$ & 1000-1400 \\
\hline & & A2 (UD) & $22-28$ & $2000-2400$ \\
\hline & & A3 (UGD) & $>30$ & $3000-3500$ \\
\hline & & A4 & $>44$ & $>4000$ \\
\hline & & A5 & $>54$ & $>5000$ \\
\hline \multirow[t]{8}{*}{2} & \multirow{8}{*}{$\begin{array}{l}\text { Sengon } \\
\text { (Paraserianthes } \\
\text { falcataria (L.) } \\
\text { Nielsen) - fast } \\
\text { growth }\end{array}$} & Length & $10-14$ & $395-470$ \\
\hline & & $1.3 \mathrm{~m}$ & $15-19$ & $495-570$ \\
\hline & & & $>20$ & $695-720$ \\
\hline & & & $>25$ & $795-875$ \\
\hline & & Length & $25-29$ & $800-916$ \\
\hline & & $2.6 \mathrm{~m}$ & $30-39$ & $925-1100$ \\
\hline & & & $40-49$ & $1125-1140$ \\
\hline & & & $>50$ & $1125-1150$ \\
\hline
\end{tabular}
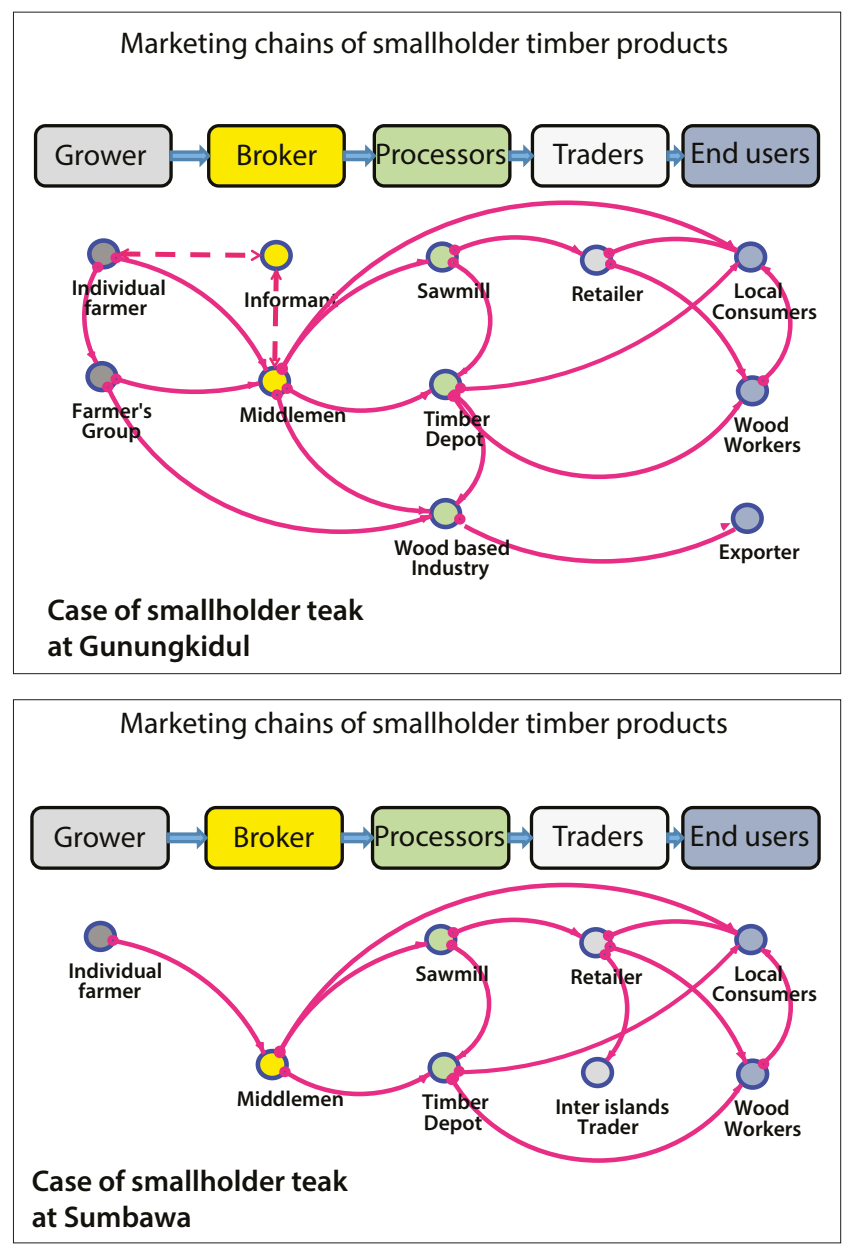

Figure 2. Comparison of marketing chains of smallholder timber at Gunungkidul and Sumbawa. the cost of a land certificate was high (around IDR 2.5 million per ha). This certificate is required to obtain a harvesting permit or Izin Pemanfaatan Kayu Tanah Milik (IPKTM). In addition, other transaction costs ${ }^{4}$ incurred per single transaction (about $5 \mathrm{~m}^{3}$ of log) can be as high as IDR 100,000 to IDR 500,000. In Gunungkidul, the cost of the timber transport document was around $7-13 \%$ of the marketing cost. In Konawe Selatan, the cost of the regional government tax and transport permit was 32\% of the marketing cost. Middlemen in most cases provide for the transaction costs, but may transfer all of the costs by lowering the farm-gate price. Current regulations tend to be a disincentive to timber production and decrease investment in smallholder timber plantations (Stewart et al. 2014a).

Recently, the government has applied the SVLK (Sistem Verifikasi Legalitas Kayu) or TLAS (Timber Legality Assurance System) to all timber that is produced in the country, including timber from smallholder plantations. This certification scheme is intended to improve the brand image of timber produced from Indonesia and in doing so, provides better market access for international trading. As this new policy creates additional transaction costs for smallholders, the government should provide incentives to compensate for this additional cost (Stewart et al. 2014b). A possible incentive is elimination of the need for a Surat Asal Usul Kayu (SKAU) or certificate of timber origin when a SVLK has already been obtained by smallholders.

\section{Recommendations}

To promote smallholder timber plantations in Indonesia, central and regional government agencies responsible for extension programs should:

- improve farmers' market position and skills - enhance farmers' knowledge of timber markets, the timber quality required by industries and the prices for timber of varying quality;

- improve farmers' silvicultural skills - facilitate training in smallholder timber plantation management. Women should be included in the training programs as they play important roles in timber plantation management;

- $\quad$ strengthen farmers' capacity in collective timber marketing -facilitate training for farmers in collective action and developing business links with timber industries. Training in timber certification could provide an entry point for improving farmers' collective actions;

The Ministry of Environment and Forestry should simplify smallholder timber trade regulations by integrating the TLAS and SKAU regulations. Farmer groups that have already obtained a TLAS certificate should be released from the obligation to provide a SKAU for their timber transaction. This will reduce the transaction costs of timber marketing and provide an incentive for farmers to engage in government timber certification programs.
4 The transaction cost was required for checking the legality of timber being transported. 


\section{References}

Ministry of Forestry Regulation No. P.01/Menhut-II/2004 on local community empowerment within and surround forest areas in social forestry. Jakarta: Ministry of Forestry of Indonesia.

Oktalina SN, Bisjoe AR, Muin N, Purwanti R, Sumirat BK, Putro WT, Utomo S, Nugroho P, Manalu P, Rohadi D, Waka AK, Irawanti S, Pramestisuka A, Syafii S, Julmansyah. 2014. Forestry livelihood framework. Report of Research Task \#2, ACIAR Project FST/2008/030 - Overcoming constraints to community-based commercial forestry in Indonesia. Canberra: Australian Centre for International Agricultural Research.2

Rohadi D. Roshetko JM, Perdana A, Blyth M, Nuryanto N, Kusumowardani N, Pramono AA, Wydiani N, Fauzi A, Sasono J, Sumardamto P, Manalu P. 2012. Improving economic outcomes for smallholders growing teak in agroforestry systems in Indonesia. Final Report ACIAR Project FST/2005/177. Canberra: Australian Centre for International Agricultural Research. Stewart HTL, Rohadi D. Manalu P, Herawati T, Oktalina SN, Rohman, Putro WT, Utomo S, Ningrum LW, Hidayat R, Irawanti S, Pramestisuka A, Parlinah N, Bisjoe AR, Muin N, Hayati N, Waka AK, Sumirat BK, Syafii S, Julmansyah, Aryanti ND, Waluyadi YK, Darisman A, Silvia D . 2014a. Research Task 3: Evaluation of the dominant business models of communitybased commercial forestry being implemented by government and the private sector. Report of a study conducted in Gunungkidul, Pati, Bulukumba, Konawe Selatan and Sumbawa, ACIAR Project FST/2008/030 - Overcoming constraints to community-based commercial forestry in Indonesia. Canberra: Australian Centre for International Agricultural Research, $46 \mathrm{pp}$.

Stewart HTL, Rohadi D and Irawanti S. 2014b. Special study into the outcomes of forest certification for smallholder forest growers. Report of a study conducted in Gunungkidul and Pati, ACIAR Project FST/2008/030 - Overcoming constraints to community-based commercial forestry in
Indonesia. Canberra: Australian Centre for International Agricultural Research.

Van de Fliert E. 2013. Social dimension analysis of community based commercial forestry in Indonesia. Report on study conducted in Gunungkidul, Pati, Bulukumba, Konawe Selatan and Sumabawa. ACIAR Project FST/2008/030 Overcoming constraints to community-based commercial forestry in Indonesia.

\section{Acknowledgments}

This policy brief is the product of collaboration among CIFOR scientists and research partners involved in FST/2008/030 Overcoming Constraints to Community-Based Commercial Forestry in Indonesia project. CIFOR would like to thank the Australian Centre for International Agricultural Research (ACIAR) for their support for this research project, as well as all partner agencies including the Australian National University; Forestry Research and Development Agency, Ministry of Forestry of Indonesia; the University of Gajah Mada; World Wide Fund for Nature (WWF) Nusa Tenggara; Trees for Trees; the local governments in Gunungkidul, Pati, Sumbawa, Bulukumba and South Konawe; as well as the community groups that helped to implement research activities. CIFOR also thanks Christopher Beadle for reviewing this policy brief. Further information about the project can be obtained from http://puspijak.org/aciar.

Authors who contributed to this policy brief (in alphabetical order) include: Abdul Kadir Waka; Achmad Darisman; Achmad Rizal Bisjoe; Aneka Prawesti Suka; Bugi Kabul Sumirat; Devi Silvia; Julmansyah; Kirsfianti Ginoga; Linda Wige Ningrum; Novita Diah Aryanti; Nunung Parlinah; Nur Hayati; Nurhaedah Muin; Philip Manalu; Rochmad Hidayat; Rohman; Setiasih Irawanti; Silvi Nur Oktalina; Singgih Utomo; Syafrudin Syafii; Wiyono T. Putro; and Yuwono Kamil Waluyadi.

\begin{tabular}{|c|c|c|}
\hline CGIAR & $\begin{array}{l}\text { RESEARCH } \\
\text { PROGRAM ON } \\
\text { Forests, Trees and } \\
\text { Agroforestry }\end{array}$ & $\begin{array}{l}\text { This research was carried out by CIFOR as part of the CGIAR Research Program on Forests, Trees and } \\
\text { Agroforestry (CRP-FTA). This collaborative program aims to enhance the management and use of forests, } \\
\text { agroforestry and tree genetic resources across the landscape from forests to farms. CIFOR leads CRP-FTA } \\
\text { in partnership with Bioversity International, CATIE, CIRAD, the International Center for Tropical Agriculture } \\
\text { and the World Agroforestry Centre. }\end{array}$ \\
\hline
\end{tabular}
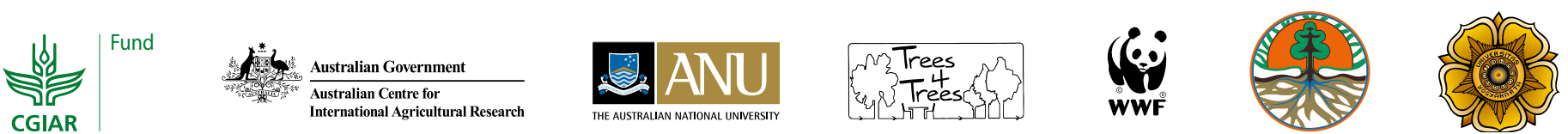